\title{
Regeneration in Spinal Disease: Therapeutic Role of Hypoxia-Inducible Factor-1 Alpha in Regeneration of Degenerative Intervertebral Disc
}

\author{
Jin-Woo Kim ${ }^{1,+} \mathbb{D}$, Neunghan Jeon ${ }^{1,+}$, Dong-Eun Shin ${ }^{2}$, So-Young Lee ${ }^{3}$, Myongwhan Kim ${ }^{1}$, Dong Hun Han ${ }^{2}$, \\ Jae Yeon Shin ${ }^{4}$ and Soonchul Lee ${ }^{2, *}$
}

check for

updates

Citation: Kim, J.-W.; Jeon, N.; Shin, D.-E.; Lee, S.-Y.; Kim, M.; Han, D.H.; Shin, J.Y.; Lee, S. Regeneration in Spinal Disease: Therapeutic Role of Hypoxia-Inducible Factor-1 Alpha in Regeneration of Degenerative Intervertebral Disc. Int. J. Mol. Sci. 2021, 22, 5281. https://doi.org/ $10.3390 /$ ijms 22105281

Academic Editor: Takashi Yurube

Received: 19 April 2021

Accepted: 13 May 2021

Published: 17 May 2021

Publisher's Note: MDPI stays neutral with regard to jurisdictional claims in published maps and institutional affiliations.

Copyright: (c) 2021 by the authors. Licensee MDPI, Basel, Switzerland. This article is an open access article distributed under the terms and conditions of the Creative Commons Attribution (CC BY) license (https:/ / creativecommons.org/licenses/by/ $4.0 /)$.
1 Department of Orthopaedic Surgery, Nowon Eulji Medical Center, Eulji University, Seoul 01830, Korea; jinwu3911@hanmail.net (J.-W.K.); bless2dness@hanmail.net (N.J.); billy0327@daum.net (M.K.)

2 Department of Orthopaedic Surgery, CHA Bundang Medical Center, CHA University, Seongnam-si 13488, Korea; shinde@cha.ac.kr (D.-E.S.); hdh7179@gmail.com (D.H.H.)

3 Department of Internal Medicine, CHA Bundang Medical Center, CHA University School of Medicine, Seongnam-si 13488, Korea; ysy0119@cha.ac.kr

4 Department of Computer Science, College of IT Engineering, SeMyung University, Jechun 27136, Korea; zhyeon838@gmail.com

* Correspondence: lsceline78@gmail.com; Tel.: +82-31-780-5289; Fax: +82-31-708-3578

+ These authors equally contributed to this work.

Abstract: The intervertebral disc (IVD) is a complex joint structure comprising three primary components-namely, nucleus pulposus (NP), annulus fibrosus (AF), and cartilaginous endplate (CEP). The IVD retrieves oxygen from the surrounding vertebral body through CEP by diffusion and likely generates ATP via anaerobic glycolysis. IVD degeneration is characterized by a cascade of cellular, compositional, structural changes. With advanced age, pronounced changes occur in the composition of the disc extracellular matrix (ECM). NP and AF cells in the IVD possess poor regenerative capacity compared with that of other tissues. Hypoxia-inducible factor (HIF) is a master transcription factor that initiates a coordinated cellular cascade in response to a low oxygen tension environment, including the regulation of numerous enzymes in response to hypoxia. HIF- $1 \alpha$ is essential for NP development and homeostasis and is involved in various processes of IVD degeneration process, promotes ECM in NP, maintains the metabolic activities of NP, and regulates dystrophic mineralization of NP, as well as angiogenesis, autophagy, and apoptosis during IVD degeneration. HIF- $1 \alpha$ may, therefore, represent a diagnostic tool for early IVD degeneration and a therapeutic target for inhibiting IVD degeneration

Keywords: hypoxia-inducible factor- $1 \alpha$; regeneration; intervertebral disc; disc degeneration; nucleus pulposus

\section{Introduction}

The intervertebral disc (IVD) links adjacent vertebral bodies and protect against damage during extremes physical loads. IVD comprises a central gelatinous nucleus pulposus (NP) surrounded by a fibrous annulus fibrosus (AF) and is joined to adjacent vertebrae by cartilaginous endplate (CEP) [1-3] NP and AF can withstand normal activities; NP can resist axial compression while AF can endure tensile stress [4]; they are supplied oxygen via diffusion through the CEP.

IVD regulates homeostasis by actively maintaining a balance between the anabolic and catabolic metabolism of IVD cells. IVD retrieves oxygen from the surrounding vertebral body through CEP via diffusion and may generate adenosine triphosphate (ATP) using anaerobic glycolysis [5,6]. The aggrecan-rich NP is an avascular tissue that is sparsely populated with NP cells in a hypoxic environment [7]. IVD is the largest avascular structure 
in the human body $[1,8]$; few blood vessels infiltrate the superficial region of the CEP and the outer third of the AF; however, none of these vessels infiltrate the NP $[9,10]$.

IVD degeneration is characterized by a cascade of cellular, compositional, structural, and functional changes [11,12]. IVD degeneration is a major cause of spinal disorders associated with low back pain, which is influenced by several factors and has high morbidity and mortality $[11,13,14]$.

Oxygen reaches the NP predominantly through diffusion, thereby imposing a hypoxic state on the NP cells $[15,16]$, which is in turn enhanced by the loss of CEP permeability during IVD degeneration [17]. Hypoxia is an important cellular stress mechanism with significant pathological implications in numerous diseases, such as cerebral ischemia, cancer, and chronic degenerative disorders [18,19].

Hypoxia-inducible factor (HIF) is a master transcription factor that initiates a coordinated cellular cascade in response to a low oxygen tension environment, including the regulation of numerous enzymes in response to hypoxia [19-26]. HIF has been shown to play an essential role in cellular and systemic homeostatic response to hypoxia. Recently, HIF expression in NP cells was reported by many groups [9,17,23,24,27-33]. Moreover, HIF- $1 \alpha$ is essential for NP development and homeostasis and could be involved in IVD degeneration in humans [34,35].

This review will summarize structure, function, and pathogenesis of IVD. Furthermore, we discuss the regulatory roles of HIF- $1 \alpha$ in the biological behaviors of IVD, current data on the expression of HIF- $1 \alpha$ in IVD, and roles of HIF- $1 \alpha$ plays in the regulation of the phenotypes, survival, metabolism, regulation of extra cellular matrix, and dystrophic mineralization of NP cells of IVD.

\section{Structure and Function of the IVD}

The anatomical function of the IVD is to stabilize the spine by anchoring adjacent vertebral bodies and to enable flexible movement of the spine, while its physiological function is to absorb shock and evenly distribute axial pressure [36].

IVD is a complex joint structure comprising three main components. NP is the center of the IVD and is gelatinous and resilient. The AF circumferentially encapsulates the NP while the CEPs are located above and below the NP and AF (Figure 1).

NP comprises proteoglycan, type II collagen fibers, and elastin fibers [37,38]. The proteoglycan of the NP largely comprises aggrecan, which has a high level of anionic glycosaminoglycan (GAG). Aggrecan is composed of a long core protein found at its center, and approximately 100 chondroitin sulfate and 30 keratan sulfate chains bound covalently to the core protein [39]. Keratan sulfate, constituting the aggrecan of NP, is longer than that in articular cartilage tissue, but is considerably shorter than chondroitin sulfate [40]. The core protein has a globular domain that can bind to hyaluronan. Thus, hundreds of aggrecans combine with hyaluronan to form large proteoglycan aggregates [40]. These proteoglycan aggregates are responsible for the hydrophilic nature of the nucleus. The rich GAG chains enable the NP to have osmotic properties and allow the retention of fluid required to maintain NP height and turgor against compressive loads.

$\mathrm{AF}$ is a heterogeneous fibrocartilaginous tissue and has been shown to consist of outer and inner AF [41]. The outer AF comprises a series of concentrically arranged lamellae, each formed by parallel bundles of type I collagen fibers. In each layer, collagen fibers are oriented approximately $60^{\circ}$ to the vertical axis of the spine and are arranged parallel to each other. Between adjacent lamellae, the collagen fibers are arranged perpendicularly to provide maximal tensile strength [38]. The inner AF serves as a transition between the outer AF and NP. The inner AF has a higher type II collagen and proteoglycan content within its interlamellar matrix than that in the outer AF [42,43]. Fibers of the outer AF are firmly anchored into the vertebral bodies, whereas the inner fibers are interconnected with the CEP [34]. 


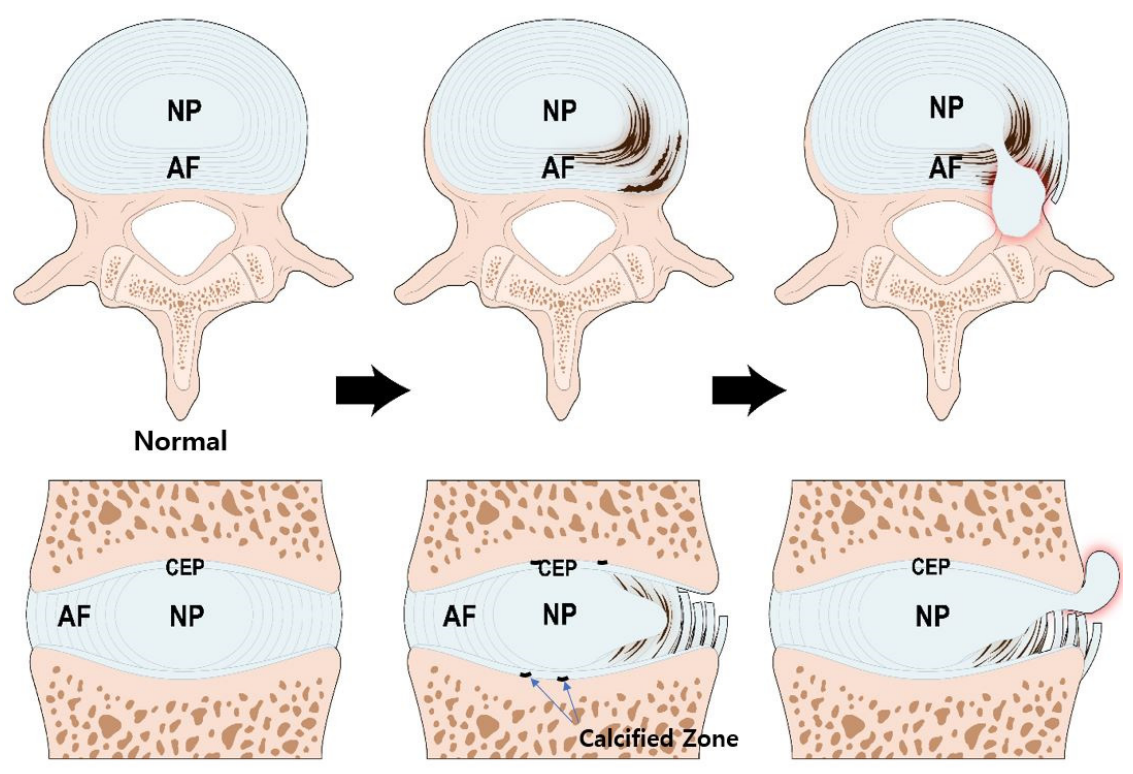

Figure 1. Structure of the IVD and pathogenesis of IVD degeneration. During the aging process, calcification occurs in the bone-cartilage junction of CEP. The calcified zone is impermeable thereby, reducing nutrient transport and inhibiting IVD cell metabolism. The NP cells, originally under adverse condition, are the first to be affected. Altered aggrecan composition and reduced type II collagen weakens the structural integrity of NP. Myxomatous degeneration in AF can disrupt its highly organized collagen fiber arrangement. These processes increase the potential IVD structural damage. IVD; intervertebral disc, NP; nucleus pulposus, AF; annulus fibrosus, CEP; cartilage endplate.

$\mathrm{NP}$ and AF act synergistically during normal activities. The NP can withstand axial compressive loads due to its intrinsic hydrostatic pressure, whereas the AF can resist heavy tensile stresses [4]. When the disc is compressed, hydrostatic pressure is generated within the NP. The NP expands radially to engage the AF, wherein tensile strength further resists expansion $[42,44]$.

The CEP is a thin plate of hyaline-like cartilage $(0.2 \sim 0.8 \mathrm{~mm})$ that primarily comprises proteoglycan and type II collagen [6]. The collagen fibers of the CEP are mainly aligned parallel to the vertebral body and are connected to the collagen fibers of the inner AF. However, the integration between collagen fibers in the NP and CEP is more convoluted [45]. The CEP is not anchored into the bony endplate; thus it can be readily separated from the vertebral body when a shearing force is applied in a traumatic situation [5]. The endplate distributes intradiscal pressures over the surface of the adjacent vertebral body and prevents pressurized NP from bulging into the vertebral body.

IVD is the largest avascular tissue in the human body. The blood vessels surrounding the IVD during the early phases of development subsequently disappear. The outer AF receives direct blood supply; however, the supply is confined to the periphery. The NP and inner AF are supplied by diffusion through the CEP. The capillary network which arises from the vertebral arteries, penetrates the subchondral bone, and terminates in loops at the bone and CEP junction [15]. The diffusivities are significantly associated with matrix porosity. The porosity of the CEP is significantly higher in the central region adjacent to the NP [46].

Diffusion through the CEP is the main nutrient supply pathway to IVD [47-49]. Small molecules, such as glucose and oxygen, leave vertebral capillaries and are diffused through the CEP, they then reach the cells of NP and AF. A concentration gradient for diffusion is established by maintaining a balance between the rate of blood supply and the rate of cellular consumption. Waste products, such as lactic acid, are removed by the reverse pathway [50]. 


\section{Pathogenesis of IVD Degeneration}

IVD degeneration is a progressive cascade of cellular, compositional, and structural changes [38,51]. Since IVD is an avascular tissue, glycolysis is the sole supply of cellular energy, which uses glucose and generates lactic acid [52]. IVD cells use less oxygen compared with other cells, consequently producing less carbon dioxide [53]; however, they require oxygen for function [54]. The viability of the disc cell is maintained when glucose is sufficient and lactic acid is regulated below a certain level [50]. In acidic environment, the rate of glycolysis and oxygen uptake decrease even when glucose levels are maintained, thus cell death increases [55].

The rates of matrix synthesis and degradation of disc cells are influenced by the local extracellular oxygen and $\mathrm{pH}$ levels [50]. The matrix synthesis rate is the highest at 5\% oxygen, and if the oxygen tension falls below $5 \%$, the synthesis rate is significantly reduced to the oxygen-tension dependent manner. At low oxygen tension, the production of macromolecules, such as sulfated GAG and protein, is greatly inhibited. Matrix component synthesis is higher at $\mathrm{pH} 7.0$, than at $\mathrm{pH} 7.4$; furthermore, when $\mathrm{pH}$ is decreased below 7.0, the synthesis rate drop steeply [56]. Matrix degradation is less sensitive to $\mathrm{pH}$; the activities of metalloproteinase, a matrix catabolic enzyme, are similar at pH 7.0 and 6.4 [57]. Therefore, an acidic $\mathrm{pH}$ increase the matrix breakdown rate by inhibiting synthesis [50].

During the aging process, calcification occurs in the bone-cartilage interface of the endplate [58], which is impermeable, preventing diffusion, reducing nutrient transport, and inhibiting disc cell metabolism [59]. The CEP tissue of degenerated IVD contains high level of calcium ions, which lowers the secretion and accumulation of type I, II collagen and proteoglycan and reduces the CEP permeability [59].

The NP, the center of the disc, has the lowest concentration of glucose and oxygen, and the highest concentration of lactic acid [52]. The activity and viability of NP cells at the center of the disk, originally under adverse conditions, are the first to be affected [60]. Early degenerative changes in the NP involve an increase in the proteolytic degradation of aggrecan, and an increase in non-aggregating proteoglycan. The accumulation of degraded proteoglycan hinders the diffusion of glucose and oxygen. The proportion of GAG chains of aggrecan also changes; chondroitin sulfates, which are longer and more negatively charged, are decreased, and heparan sulfate and keratan sulfate, which are shorter and less negatively charged, are increased. These changes reduce the viscosity and hydrostatic pressure of NP. Thus, the ability of the NP to resist axial loading is decreased, the height of the NP is decreased, and the NP become bulging [61].

Major collagens constituting the IVD are type I and type II collagen, which are distributed radially in opposing concentration gradients. Type I collagen predominantly comprises fiber bundles of the $\mathrm{AF}$, whereas type II collagen is the principal component of the random fibrillar NP network [62]. The synthesis of type II collagen peaks during early life but decreases gradually as degeneration progresses. The number of collagen cross-links is decreased due to the reduction in type II collagen; therefore, the structural integrity of the NP is weakened [63].

Type I collagen replaces type II collagen in the NP, making it a more fibrotic tissue. When degeneration proceeds, myxomatous degeneration occurs in the AF, disrupting the highly organized collagen fiber arrangement of $\mathrm{AF}$, and disorganizing the collagen and elastin networks. When the collagen network is damaged, the biomechanics of the disc are significantly altered and the potential for structural damage is increased [36].

\section{Expression of HIF and Signal Transduction of HIF-1 $\alpha$ in IVD}

\subsection{Expression Patterns of HIF-1 $\alpha$ and HIF- $2 \alpha$ in IVD}

Since the IVD is an avascular structure, its disc supply depends mainly on diffusion. A low supply of nutrients causes a decrease in oxygen, affecting cell function and synthesis of the extracellular matrix $[15,50]$. 
The HIF family of proteins contains HIF-1, HIF-2, and HIF-3, comprising an $\alpha$-subunit and a constitutively expressed $\beta$-subunit. Among the HIF family, HIF-1 and HIF-2 play a crucial role for the biologic regulation of NP cells.

HIF-1 is an essential transcription factor that regulates the survival and functioning of NP cells in the avascular niche of the IVD [34,64]. Richardson et al. [17] demonstrated the expression of HIF- $1 \alpha$ in normal and degenerative IVDs, and HIF- $1 \alpha$ was markedly expressed in NP cells of degenerative IVD. Through western blot and immunohistochemistry analysis, Rajpurohit et al. [24] revealed that the expression of HIF-1 $\alpha$ was only observed in $\mathrm{NP}$ cells, but not in AF and CEP cells. Ha et al. [32] revealed that HIF-1 $\alpha$ expression and apoptosis occur in herniated disc areas and observed a considerable correlation between the expression of HIF- $1 \alpha$ and apoptosis.

HIF- $2 \alpha$ of NP cells has been reported in rats and its transactivation significantly increased under hypoxia [21]. Huang et al. suggested that HIF-2 $\alpha$ is a catabolic regulator during disc degeneration, which its suppression decelerate ECM degradation and hence it may be a therapeutic target against IVD degeneration [65].

\subsection{Signal Transduction Pathway of HIF-1 $\alpha$ in IVD}

The activity of HIF-1 $\alpha$ within a cell depends on oxygen sensitivity, which decrease in response to normoxia and increases under hypoxic conditions (Figure 2).

\section{A. Normoxia}

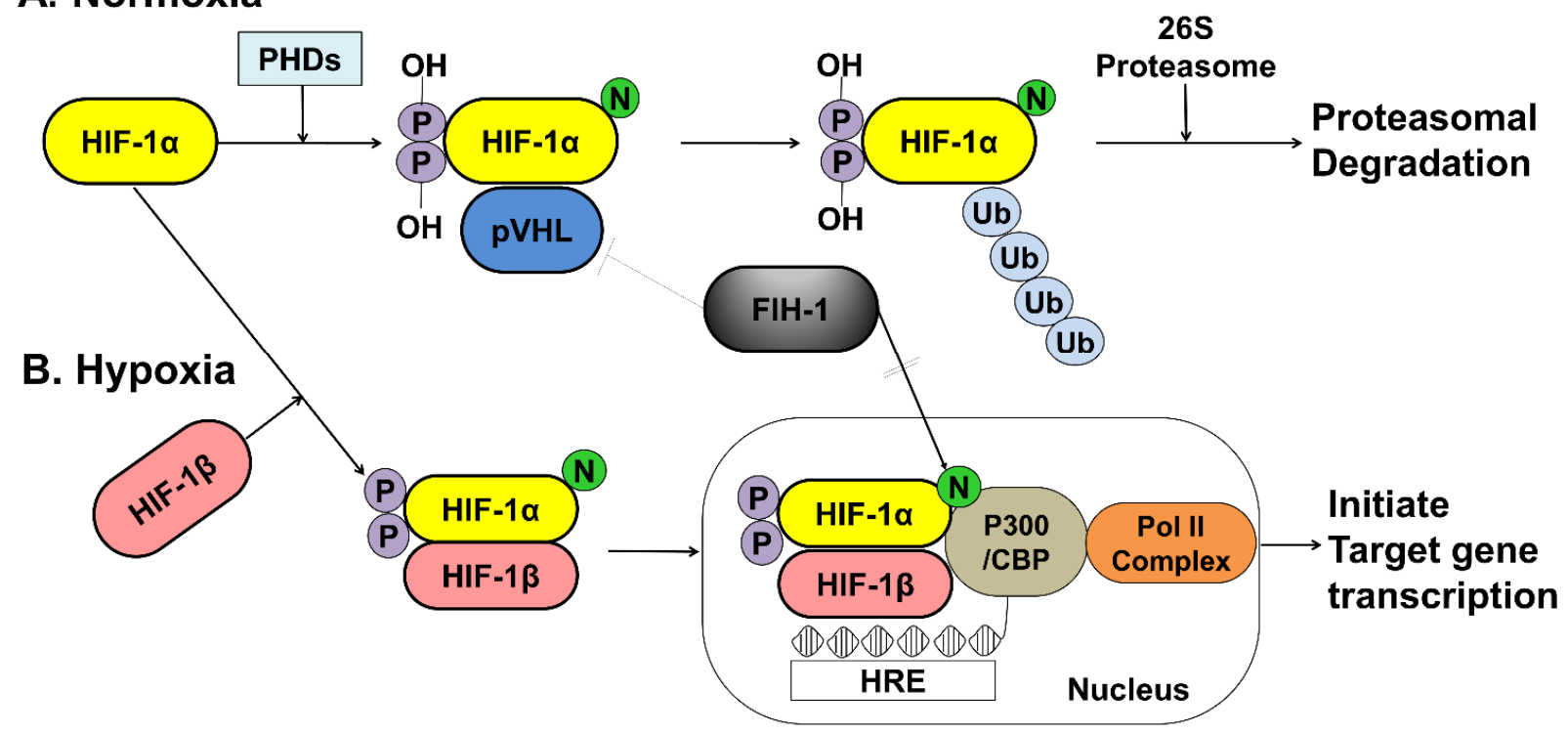

Figure 2. A schematic representation of the oxygen-dependent regulation of HIF-1 $\alpha$ under normoxic and hypoxic conditions. (A) Under normoxic conditions, HIF-1 $\alpha$ is hydroxylated at specific proline residues by PHD enzymes on the proline residues, which leads to polyubiquitination and proteasomal degradation of HIF- $1 \alpha$ by the VHL protein, a component of E3 ubiquitinprotein ligase. (B) Under hypoxic conditions, PHD enzyme activity is inhibited, thereby allowing HIF-1 $\alpha$ to accumulate and translocate to the nucleus, where it dimerizes with HIF-1 $\beta$ and binds to the HRE sequences of target gene promoters. The FIH-1, an asparagine hydroxylase, regulates the transcriptional activity of HIF-1 binding to VHL and represses HIF-1 transactivation by preventing the binding of the transcriptional coactivator p300/CBP to the HIF-1 $\alpha$. HIF; hypoxia inducible factor, PHDs; prolyl hydroxylase domain proteins, pVHL; protein von Hippel Lindau, CBP; Creb-binding protein, HRE; hypoxia-response element, Pol II; DNA polymerase II complex, Ub; Ubiquitous, FIH-1; factor inhibiting HIF-1.

Under normoxic conditions, HIF- $1 \alpha$ is hydroxylated at two specific proline residues (Pro402 and Pro564) in the oxygen-dependent degradation domain by the prolyl 4-hydroxylase domain-containing (PHD) enzyme, which leads to polyubiquitination and proteasomal degradation of HIF- $1 \alpha$ by the von Hippel-Lindau tumor suppressor protein, a component of E3 ubiquitin-protein ligase $[66,67]$. Under hypoxic conditions, PHD enzyme activity is inhibited, and HIF- $1 \alpha$ is spared from polyubiquitination and proteasomal degradation, 
thereby allowing HIF- $1 \alpha$ to accumulate and translocate to the nucleus, where it dimerizes with HIF- $1 \beta$ and binds to the hypoxia-responsive element (HRE) sequences of target gene promoters. This protein complex, which binds to an enhancer, the HRE, in HIF-a target genes, initiates gene transcription. Semenza et al. reported that the factor inhibiting HIF-1 (FIH-1), which is an asparagine hydroxylase, and regulates the transcriptional activity of HIF-1, which also demonstrates that FIH-1 binds to VHL [68]. The FIH-1 hydroxylation of Asn 803 on HIF- $1 \alpha$ represses HIF- $1 \alpha$ transactivation by preventing the binding of the transcriptional coactivator p300/CBP to the HIF- $1 \alpha$ C-transactivation domains $[69,70]$ (Figure 2).

The Fas and Fas ligand (FasL) system transfers a death signal that rapidly commits cells to apoptosis and is expressed together in the disc of herniated IVD [71]. Fas can be expressed in various cell types, whereas FasL expression appears to be more restricted. FasL, a type II membrane protein of $36 \mathrm{kDa}$, belongs to the tumor necrosis factor family, and upon binding to the Fas, it acts as a cell-death-triggering ligand that induces apoptosis [72]. Zeng et al. [30] found that HIF-1 $\alpha$ may induce the expression of Galectin-3(gal-3) and sequentially inhibit Fas/FasL-mediated apoptosis of NP cells and further confirmed that HIF- $1 \alpha$ combined with gal-3 HRE that site-directed mutagenesis of HRE completely blocked hypoxic induction of gal-3 promoter activity.

\section{Regeneration for IVD Degeneration-Focused on HIF-1 $\alpha$}

5.1. Main Roles of HIF-1 $\alpha$ in IVD Degeneration

\subsubsection{Promotion of Extracellular Matrix in NP Cells}

Regulation of human NP survival and ECM synthesis are therapeutic strategies for IVD degeneration [14] (Figure 3). In the NP of the disc, ECM is predominantly composed of proteoglycans and type II collagen [12]. Proteoglycans are abundant in the NP, which permits the IVD to resist compressive loads for spinal stability and allows slight movement of the spine [22]. Recently, biological studies on the prevention of early disc degeneration by promoting ECM synthesis, including NP cells, by upregulating HIF- $1 \alpha$ have been reported [73-78]. Wang et al. [79] revealed that the high expression of long non-coding RNA(RP11-296A18.3) promotes HIF-1 $\alpha$ expression through low expression of mitochondrial RNA (miR-138), thus promoting NP cell proliferation and ECM synthesis. Chen et al. [76] revealed that the PHD/HIF-1/CA12 pathway may affect disc degeneration by regulating ECM anabolism, and this pathway activity could be a valuable therapeutic approach to IVD degeneration.

The receptors, ligands, and target genes of the NOTCH1 signaling pathway are expressed in IVD cells, and NOTCH1 signaling is crucial for the maintenance of NP cell proliferation under hypoxic conditions of the IVD [80]. HIF-1 $\alpha$ increases the expression of type II collagen and aggrecan in NP cells via the NOTCH1 pathway [81]. Further research on ECM synthesis in NP cells by promoting HIF-1 $\alpha$, which is the most crucial mechanism, is warranted.

\subsubsection{Maintenance of the Metabolic Activity of NP Cells}

HIF plays a significant role in the preservation of the metabolic activities of NP cells in IVD $[23,24,82]$ (Figure 3). Hypoxia-responsive glucose transporter (GLUT), located on the cell membrane, is an important gene for promoting anaerobic glycolysis of NP cells in IVD [31,83]. Richardson et al. [17] showed that HIF- $1 \alpha$, GLUT-1, GLUT-3, and GLUT-9 were co-expressed in normal human IVDs, and an increase in HIF-1 $\alpha$ expression was associated with an increase in the expression of GLUT-1, GLUT-3, and GLUT-9 in NP cells; however, this association has not been observed in AF cells. Interestingly, they also observed that the expression of GLUTs increased as IVD degeneration progressed. HIF-1 maintains the metabolic activities of NP cells under a hypoxic environment in IVDs, mainly by regulating the expression of GLUT-1, GLUT-3, and GLUT-9. 


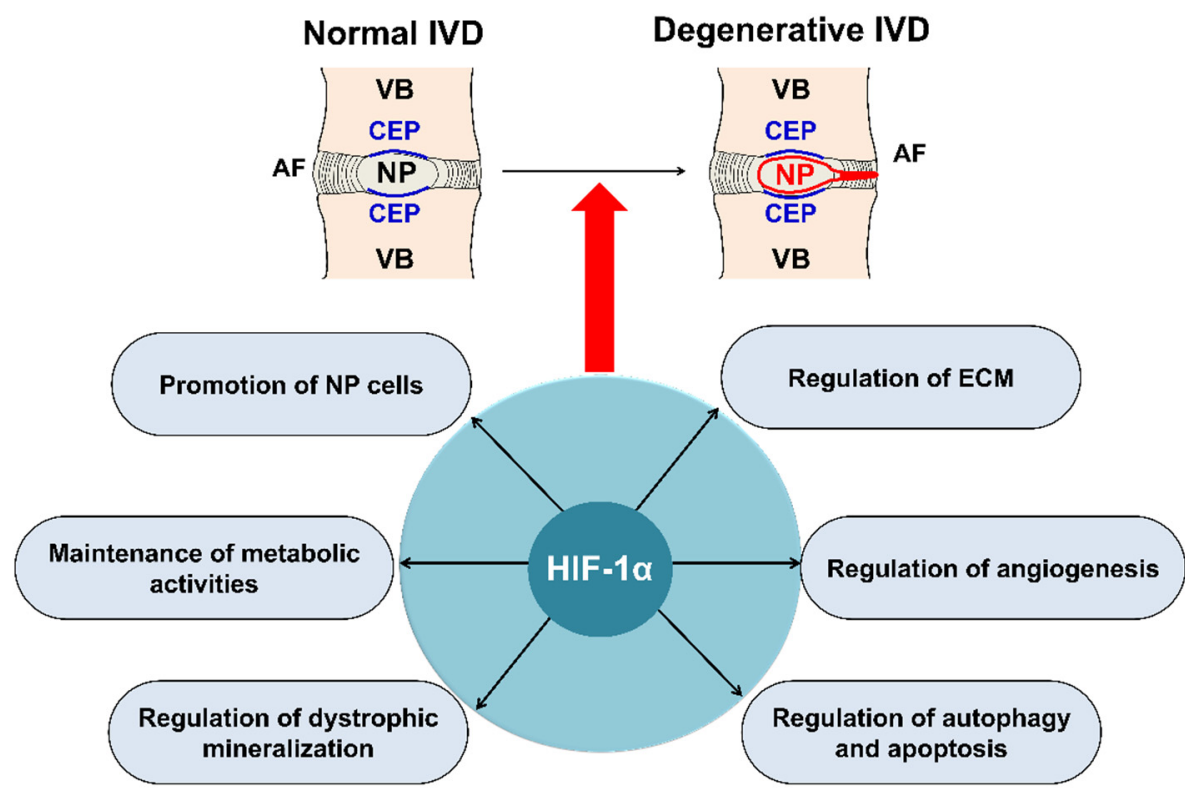

Figure 3. Main roles of HIF-1 $\alpha$ in IVD degeneration. HIF- $1 \alpha$, involved in IVD degeneration, promotes ECM in NP, maintains the metabolic activities of NP, regulates dystrophic mineralization of NP, and regulates angiogenesis, autophagy, and apoptosis during IVD degeneration. HIF; hypoxia inducible factor, IVD; intervertebral disc, ECM; extracellular matrix, NP; nucleus pulposus, AF; annulus fibrosus, CEP; cartilage endplate, VB; vertebral body.

HIF-1 $\alpha$ also regulates mitochondrial energy metabolism [83,84]. Papandreou et al. [84] showed that HIF-1 $\alpha$ stimulates glycolysis and actively inhibits mitochondrial function and oxygen consumption by inducing pyruvate dehydrogenase kinase 1 .

\subsubsection{Regulation of Dystrophic Mineralization in NP Cells}

Dystrophic mineralization due to aging and injury is a common problem observed in soft tissues and can cause several diseases, including calcification of cartilage, resulting in osteoarthritis [85,86]. The CEP calcification associated with the severity of IVD degeneration [87] causes the permeability of CEP to decline, and nutrients and metabolic waste in the IVD may cause the occurrence and progression of IVD degeneration through an increase in HIF-1 $\alpha$ [88]. Previous studies have shown that mutations in ankylosis protein homolog gene (ANK), a pyrophosphate transporter, could result in abnormal dystrophic mineralization in joints and bone $[89,90]$ and the hypoxic status may influence ANK expression, which may be mediated by HIF- $1 \alpha$. HIF- $1 \alpha$ controls the dystrophic mineralization of NP cells by suppressing ANK expression [29]. Dystrophic mineralization caused by abnormal expression of ANK can cause the IVD degeneration [29,91]. Skubutyte et al. [29] found that ANK was expressed in calcified areas of the CEP, and HIF- $1 \alpha$ directly downregulate ANK expression, indicating that expression of HIF- $1 \alpha$ can maintain the physiological level of ANK under physiological conditions, thereby preventing the occurrence of dystrophic mineralization and promoting NP cells to adapt to the hypoxic environment.

\subsubsection{Regulation of Angiogenesis during IVD Degeneration}

Vascular endothelial growth factor (VEGF) and its receptors (VEGFRs) play important roles in both physiological and pathological angiogenesis [92]. Han et al. [93] demonstrated that the VEGF gene may increase the risk for the development of IVD degeneration and is also positively related to the severity of IVD degeneration. Vascularized IVD cells improve blood circulation and the nutrition of NP cells and play an important role in the spontaneous absorption of herniated IVD [94,95]. Kwon et al. [96] demonstrated that VEGF expression significantly activates HIF- $1 \alpha$ under hypoxia during an inflammatory reaction. Agrawal et al. [21] demonstrated that HIF-1 $\alpha$ may enhance NP cell survival 
in a specialized microenvironment of the IVD via HIF- $1 \alpha$-mediated VEGF expression. Wu et al. [97] indicated that the HIF-1 $\alpha$ /VEGF signaling pathway plays a crucial role in the survival of NP cells and maintenance of the ECM balance in the development of IVD degeneration.

\subsubsection{Autophagy and Apoptosis during IVD Degeneration}

Autophagy, the process of non-apoptotic, programmed cell death, is a physiological response to hypoxia and exhibits a complicated association with hypoxia [98,99]. The level of autophagy changes according to IVD degeneration and age $[98,100]$. It has been shown that NP cells show higher autophagy activity under normoxia than under hypoxia $[98,101]$. Hypoxic conditions facilitate NP cell survival via the downregulation of excessive autophagy, by restricting the production of reactive oxygen species and inactivating the AMPK/mTOR signaling pathway, which may be regulated by HIF-1 $\alpha$ [101].

Excessive apoptosis and senescence of NP cells may lead to degeneration of the ECM; hence, HIF- $1 \alpha$ could be a therapeutic target against IVD degeneration [102]. Using surgical IVD specimens, Gruber et al. [103] demonstrated that a high incidence of apoptosis was detected in IVD. HIF- $1 \alpha$ is positively associated with NP cell apoptosis in herniated discs [32] and enhances the ability of NP cells to adapt to hypoxia and survive under hypoxic conditions.

\subsection{HIF-1 $\alpha$ Development Strategies for IVD Regeneration}

Among the members of the HIF family, HIF- $1 \beta$ is a stable constitutively expressed protein in the nucleus and is not affected by the hypoxic state. However, the HIF- $1 \alpha$ subunit has a short half-life of less than $5 \mathrm{~min}$ because under hypoxic conditions, PHD may be deactivated and cause degradation of HIF- $1 \alpha$. HIF- $1 \alpha$ is the most important molecule that regulates the IVD degeneration [104].

Transplantation of NP cells into the IVD may be an effective treatment for degeneration. Wang et al. [105] demonstrated that the antiapoptotic effect and migratory capacity of transplanted NP cells increased the expression of ECM, promoted NP cell migration to the damaged area, and alleviated IVD degeneration. The expression of HIF- $1 \alpha$, which is enhanced under hypoxia, can promote cell proliferation, and maintain the functional phenotype of NP cells. Therefore, it is important to isolate and amplify NP cells during hypoxia for cell transplantation, which depends on the HIF-1 $\alpha /$ GLUT 1 pathway [106].

Even under normoxic conditions, constitutively active HIF- $1 \alpha$ can be obtained by point mutation or deletion and may be therapeutic a target for IVD degeneration. Previous studies have focused on the regulation of non-coding RNA that are associated with HIF- $1 \alpha$ in IVD $[79,104,105,107]$. HIF-1 $\alpha$ may also be a therapeutic target for non-coding RNAs regulating IVD degeneration. Liu et al. [104] reviewed the role of HIF-1 $\alpha$ and suggested that HIF- $1 \alpha$ and EMC can be used the evaluation criteria for the pathological diagnosis of the "internal grading" of the degree of microenvironmental disorders in IVD degeneration. Thus, HIF- $1 \alpha$ may be a diagnostic tool for early IVD degeneration and can act as a therapeutic target for inhibiting them.

\section{Conclusions}

HIF- $1 \alpha$ in NP cells represents a potential early diagnostic marker and therapeutic target against IVD degeneration. Development of diagnostic and therapeutic strategies targeting HIF- $1 \alpha$ to promote ECM and regulate dystrophic mineralization in NP cells, maintain metabolic activity of NP cells, and regulate angiogenesis, autophagy, and apoptosis during IVD may be an effective treatment strategy for the prevention of IVD degeneration. Further studies on HIF-1 $\alpha$ regulated pathways in discs may be valuable for early diagnosis, prevention, and treatment of IVD degeneration. 
Author Contributions: J.-W.K. and N.J. contributed equally to this work and should be considered co-first authors. S.L. and J.-W.K. conceived this idea. J.-W.K., N.J., S.-Y.L. and J.Y.S. collected related references and wrote the manuscript. J.-W.K., D.-E.S., M.K. and D.H.H. drew the figures. J.-W.K. and S.L. supervised and revised the manuscript. All authors have read and agreed to the published version of the manuscript.

Funding: This work was supported by the National Research Foundation of Korea (NRF) grant funded by the Korea government (MSIP) (No. NRF-2019R1C1C1005658, NRF-2019R1C1C1004017, and NRF-2019R1A2C4070492).

Institutional Review Board Statement: Not applicable.

Informed Consent Statement: Not applicable.

Data Availability Statement: Not applicable.

Conflicts of Interest: The authors declare no conflict of interest.

$\begin{array}{ll}\text { Abbreviations } \\ \text { IVD } & \text { intervertebral disc } \\ \text { ATP } & \text { adenosine triphosphate } \\ \text { HIF-1 } \alpha & \text { hypoxia-inducible factor-1 alpha } \\ \text { NP } & \text { nucleus pulposus } \\ \text { AF } & \text { annulus fibrosus } \\ \text { CEP } & \text { cartilaginous end plate } \\ \text { GAG } & \text { anionic glycosaminoglycan } \\ \text { PHD } & \text { prolyl 4-hydroxylase domain-containing } \\ \text { VHL } & \text { von Hippel-Lindau tumor suppressor } \\ \text { HRE } & \text { hypoxia responsive element } \\ \text { FIH-1 } & \text { factor inhibiting HIF-1 } \\ \text { C-TAD } & \text { C-transactivation domains } \\ \text { FasL } & \text { Fas ligand } \\ \text { ECM } & \text { extracellular matrix } \\ \text { GLUT } & \text { glucose transporter } \\ \text { ANK } & \text { ankylosis protein homolog gene } \\ \text { VEGF } & \text { vascular endothelial growth factor } \\ \text { VEGFR } & \text { vascular endothelial growth factor receptor } \\ \text { AMPK } & \text { adenosine 5'-monophosphate-activated protein kinase } \\ \text { mTOR } & \text { mechanistic target of rapamycin }\end{array}$

\section{References}

1. Fournier, D.E.; Kiser, P.K.; Shoemaker, J.K.; Battie, M.C.; Seguin, C.A. Vascularization of the human intervertebral disc: A scoping review. JOR Spine 2020, 3, e1123. [CrossRef]

2. Choi, H.; Tessier, S.; Silagi, E.S.; Kyada, R.; Yousefi, F.; Pleshko, N.; Shapiro, I.M.; Risbud, M.V. A novel mouse model of intervertebral disc degeneration shows altered cell fate and matrix homeostasis. Matrix Biol. 2018, 70, 102-122. [CrossRef]

3. Tian, Y.; Yuan, W.; Li, J.; Wang, H.; Hunt, M.G.; Liu, C.; Shapiro, I.M.; Risbud, M.V. TGF $\beta$ regulates Galectin-3 expression through canonical Smad3 signaling pathway in nucleus pulposus cells: Implications in intervertebral disc degeneration. Matrix Biol. 2016, 50, 39-52. [CrossRef]

4. Korecki, C.L.; MacLean, J.J.; Iatridis, J.C. Dynamic compression effects on intervertebral disc mechanics and biology. Spine 2008, 33, 1403-1409. [CrossRef] [PubMed]

5. Berg-Johansen, B.; Fields, A.J.; Liebenberg, E.C.; Li, A.; Lotz, J.C. Structure-function relationships at the human spinal disc-vertebra interface. J. Orthop. Res. 2018, 36, 192-201. [CrossRef] [PubMed]

6. Fields, A.J.; Ballatori, A.; Liebenberg, E.C.; Lotz, J.C. Contribution of the endplates to disc degeneration. Curr. Mol. Biol. Rep. 2018, 4, 151-160. [CrossRef]

7. Bartels, E.M.; Fairbank, J.C.; Winlove, C.P.; Urban, J.P. Oxygen and lactate concentrations measured in vivo in the intervertebral discs of patients with scoliosis and back pain. Spine 1998, 23, 1-7; discussion 8. [CrossRef] [PubMed]

8. Taylor, J.R. Growth of human intervertebral discs and vertebral bodies. J. Anat. 1975, 120, 49-68.

9. Fujita, N.; Markova, D.; Anderson, D.G.; Chiba, K.; Toyama, Y.; Shapiro, I.M.; Risbud, M.V. Expression of prolyl hydroxylases (PHDs) is selectively controlled by HIF-1 and HIF-2 proteins in nucleus pulposus cells of the intervertebral disc: Distinct roles of PHD2 and PHD3 proteins in controlling HIF-1alpha activity in hypoxia. J. Biol. Chem. 2012, 287, 16975-16986. [CrossRef] 
10. Rudert, M.; Tillmann, B. Lymph and blood supply of the human intervertebral disc. Cadaver study of correlations to discitis. Acta Orthop. Scand. 1993, 64, 37-40. [CrossRef] [PubMed]

11. Weber, K.T.; Jacobsen, T.D.; Maidhof, R.; Virojanapa, J.; Overby, C.; Bloom, O.; Quraishi, S.; Levine, M.; Chahine, N.O. Developments in intervertebral disc disease research: Pathophysiology, mechanobiology, and therapeutics. Curr. Rev. Musculoskelet. Med. 2015, 8, 18-31. [CrossRef] [PubMed]

12. Le Maitre, C.L.; Pockert, A.; Buttle, D.J.; Freemont, A.J.; Hoyland, J.A. Matrix synthesis and degradation in human intervertebral disc degeneration. Biochem. Soc. Trans. 2007, 35, 652-655. [CrossRef]

13. Li, Y.; Liu, S.; Pan, D.; Xu, B.; Xing, X.; Zhou, H.; Zhang, B.; Zhou, S.; Ning, G.; Feng, S. The potential role and trend of HIF-1 $\alpha$ in intervertebral disc degeneration: Friend or foe? (Review). Mol. Med. Rep. 2021, 23. [CrossRef] [PubMed]

14. Li, H.; Liang, C.Z.; Chen, Q.X. Regulatory role of hypoxia inducible factor in the biological behavior of nucleus pulposus cells. Yonsei Med. J. 2013, 54, 807-812. [CrossRef] [PubMed]

15. Urban, J.P.; Smith, S.; Fairbank, J.C. Nutrition of the intervertebral disc. Spine 2004, 29, 2700-2709. [CrossRef]

16. Urban, J.P. The role of the physicochemical environment in determining disc cell behaviour. Biochem. Soc. Trans. 2002, 30 Pt 6 , 858-864. [CrossRef]

17. Richardson, S.M.; Knowles, R.; Tyler, J.; Mobasheri, A.; Hoyland, J.A. Expression of glucose transporters GLUT-1, GLUT-3, GLUT-9 and HIF-1alpha in normal and degenerate human intervertebral disc. HistoChem. Cell Biol. 2008, 129, 503-511. [CrossRef]

18. Semenza, G.L. Hypoxia-inducible factor 1: Oxygen homeostasis and disease pathophysiology. Trends Mol. Med. 2001, 7, 345-350. [CrossRef]

19. Carmeliet, P.; Dor, Y.; Herbert, J.M.; Fukumura, D.; Brusselmans, K.; Dewerchin, M.; Neeman, M.; Bono, F.; Abramovitch, R.; Maxwell, P.; et al. Role of HIF-1alpha in hypoxia-mediated apoptosis, cell proliferation and tumour angiogenesis. Nature 1998, 394, 485-490. [CrossRef]

20. Zhao, J.; Zhang, P.; Qin, L.; Pan, X.H. Hypoxia is essential for bone-tendon junction healing: The molecular biological evidence. Int. Orthop. 2011, 35, 925-928. [CrossRef]

21. Agrawal, A.; Gajghate, S.; Smith, H.; Anderson, D.G.; Albert, T.J.; Shapiro, I.M.; Risbud, M.V. Cited2 modulates hypoxia-inducible factor-dependent expression of vascular endothelial growth factor in nucleus pulposus cells of the rat intervertebral disc. Arthritis Rheum. 2008, 58, 3798-3808. [CrossRef] [PubMed]

22. Podjarny, E.; Bernheim, J.; Hasdan, G.; Karsh, D.; Rashid, G.; Green, J.; Katz, B.; Bernheim, J. Additive renoprotective effect of candesartan and tetrahydrobiopterin in rats after 5/6 nephrectomy. Nephrol. Dial. Transplant. 2007, 22, 1864-1872. [CrossRef]

23. Risbud, M.V.; Guttapalli, A.; Stokes, D.G.; Hawkins, D.; Danielson, K.G.; Schaer, T.P.; Albert, T.J.; Shapiro, I.M. Nucleus pulposus cells express HIF-1 alpha under normoxic culture conditions: A metabolic adaptation to the intervertebral disc microenvironment. J. Cell Biochem. 2006, 98, 152-159. [CrossRef] [PubMed]

24. Rajpurohit, R.; Risbud, M.V.; Ducheyne, P.; Vresilovic, E.J.; Shapiro, I.M. Phenotypic characteristics of the nucleus pulposus: Expression of hypoxia inducing factor-1, glucose transporter-1 and MMP-2. Cell Tissue Res. 2002, 308, 401-407. [CrossRef] [PubMed]

25. Semenza, G.L. HIF-1: Mediator of physiological and pathophysiological responses to hypoxia. J. Appl. Physiol. 2000, 88, 1474-1480. [CrossRef]

26. Semenza, G.L.; Wang, G.L. A nuclear factor induced by hypoxia via de novo protein synthesis binds to the human erythropoietin gene enhancer at a site required for transcriptional activation. Mol. Cell Biol. 1992, 12, 5447-5454. [CrossRef] [PubMed]

27. Fujita, N.; Chiba, K.; Shapiro, I.M.; Risbud, M.V. HIF-1alpha and HIF-2alpha degradation is differentially regulated in nucleus pulposus cells of the intervertebral disc. J. Bone Miner. Res. 2012, 27, 401-412. [CrossRef]

28. Gogate, S.S.; Nasser, R.; Shapiro, I.M.; Risbud, M.V. Hypoxic regulation of $\beta$-1,3-glucuronyltransferase 1 expression in nucleus pulposus cells of the rat intervertebral disc: Role of hypoxia-inducible factor proteins. Arthritis Rheum. 2011, 63, 1950-1960. [CrossRef]

29. Skubutyte, R.; Markova, D.; Freeman, T.A.; Anderson, D.G.; Dion, A.S.; Williams, C.J.; Shapiro, I.M.; Risbud, M.V. Hypoxiainducible factor regulation of ANK expression in nucleus pulposus cells: Possible implications in controlling dystrophic mineralization in the intervertebral disc. Arthritis Rheum. 2010, 62, 2707-2715. [CrossRef]

30. Zeng, Y.; Danielson, K.G.; Albert, T.J.; Shapiro, I.M.; Risbud, M.V. HIF-1 alpha is a regulator of galectin-3 expression in the intervertebral disc. J. Bone Miner. Res. 2007, 22, 1851-1861. [CrossRef]

31. Agrawal, A.; Guttapalli, A.; Narayan, S.; Albert, T.J.; Shapiro, I.M.; Risbud, M.V. Normoxic stabilization of HIF-1alpha drives glycolytic metabolism and regulates aggrecan gene expression in nucleus pulposus cells of the rat intervertebral disk. Am. $J$. Physiol. Cell Physiol. 2007, 293, C621-C631. [CrossRef] [PubMed]

32. Ha, K.Y.; Koh, I.J.; Kirpalani, P.A.; Kim, Y.Y.; Cho, Y.K.; Khang, G.S.; Han, C.W. The expression of hypoxia inducible factor-1alpha and apoptosis in herniated discs. Spine 2006, 31, 1309-1313. [CrossRef] [PubMed]

33. Neucere, J.N.; Godshall, M.A. Effects of base-soluble proteins and methanol-soluble polysaccharides from corn on mycelial growth of Aspergillus flavus. Mycopathologia 1991, 113, 103-108. [CrossRef]

34. Merceron, C.; Mangiavini, L.; Robling, A.; Wilson, T.L.; Giaccia, A.J.; Shapiro, I.M.; Schipani, E.; Risbud, M.V. Loss of HIF-1alpha in the notochord results in cell death and complete disappearance of the nucleus pulposus. PLoS ONE 2014, 9, e110768. [CrossRef]

35. Meng, X.; Zhuang, L.; Wang, J.; Liu, Z.; Wang, Y.; Xiao, D.; Zhang, X. Hypoxia-inducible factor (HIF)-1alpha knockout accelerates intervertebral disc degeneration in mice. Int. J. Clin. Exp. Pathol. 2018, 11, 548-557. [PubMed] 
36. Buckwalter, J.A. Aging and degeneration of the human intervertebral disc. Spine 1995, 20, 1307-1314. [CrossRef]

37. Adams, P.; Eyre, D.R.; Muir, H. Biochemical aspects of development and ageing of human lumbar intervertebral discs. Rheumatol. Rehabil. 1977, 16, 22-29. [CrossRef]

38. Walker, M.H.; Anderson, D.G. Molecular basis of intervertebral disc degeneration. Spine J. 2004, 4 (Suppl. S6), 158S-166S. [CrossRef]

39. Jordao, H.W.; McKenna, G.; McMenamin, U.C.; Kunzmann, A.T.; Murray, L.J.; Coleman, H.G. The association between selfreported poor oral health and gastrointestinal cancer risk in the UK Biobank: A large prospective cohort study. United Eur. Gastroenterol. J. 2019, 7, 1241-1249. [CrossRef] [PubMed]

40. Feng, H.; Danfelter, M.; Stromqvist, B.; Heinegard, D. Extracellular matrix in disc degeneration. J. Bone Jt. Surg. Am. 2006, 88 (Suppl. S2), 25-29.

41. Marchand, F.; Ahmed, A.M. Investigation of the laminate structure of lumbar disc anulus fibrosus. Spine 1990, 15, 402-410. [CrossRef]

42. Humzah, M.D.; Soames, R.W. Human intervertebral disc: Structure and function. Anat. Rec. 1988, 220, 337-356. [CrossRef] [PubMed]

43. Roughley, P.J.; Melching, L.I.; Heathfield, T.F.; Pearce, R.H.; Mort, J.S. The structure and degradation of aggrecan in human intervertebral disc. Eur. Spine J. 2006, 15 (Suppl. S3), S326-S332. [CrossRef] [PubMed]

44. Hukins, D.W. A simple model for the function of proteoglycans and collagen in the response to compression of the intervertebral disc. Proc. Biol. Sci. 1992, 249, 281-285. [PubMed]

45. Wade, K.R.; Robertson, P.A.; Broom, N.D. A fresh look at the nucleus-endplate region: New evidence for significant structural integration. Eur. Spine J. 2011, 20, 1225-1232. [CrossRef] [PubMed]

46. Wu, Y.; Cisewski, S.E.; Wegner, N.; Zhao, S.; Pellegrini, V.D., Jr.; Slate, E.H.; Yao, H. Region and strain-dependent diffusivities of glucose and lactate in healthy human cartilage endplate. J. Biomech. 2016, 49, 2756-2762. [CrossRef]

47. Maroudas, A.; Stockwell, R.A.; Nachemson, A.; Urban, J. Factors involved in the nutrition of the human lumbar intervertebral disc: Cellularity and diffusion of glucose in vitro. J. Anat. 1975, 120, 113-130.

48. Nachemson, A.; Lewin, T.; Maroudas, A.; Freeman, M.A. In vitro diffusion of dye through the end-plates and the annulus fibrosus of human lumbar inter-vertebral discs. Acta Orthop. Scand. 1970, 41, 589-607. [CrossRef]

49. Ogata, K.; Whiteside, L.A. 1980 Volvo award winner in basic science. Nutritional pathways of the intervertebral disc. An experimental study using hydrogen washout technique. Spine 1981, 6, 211-216. [CrossRef]

50. Grunhagen, T.; Wilde, G.; Soukane, D.M.; Shirazi-Adl, S.A.; Urban, J.P. Nutrient supply and intervertebral disc metabolism. J Bone Jt. Surg. Am. 2006, 88 (Suppl. S2), 30-35.

51. Ashinsky, B.G.; Gullbrand, S.E.; Wang, C.; Bonnevie, E.D.; Han, L.; Mauck, R.L.; Smith, H.E. Degeneration alters structure-function relationships at multiple length-scales and across interfaces in human intervertebral discs. J. Anat. 2021, 238, 986-998. [CrossRef] [PubMed]

52. Holm, S.; Maroudas, A.; Urban, J.P.; Selstam, G.; Nachemson, A. Nutrition of the intervertebral disc: Solute transport and metabolism. Connect Tissue Res. 1981, 8, 101-119. [CrossRef] [PubMed]

53. Bibby, S.R.; Jones, D.A.; Ripley, R.M.; Urban, J.P. Metabolism of the intervertebral disc: Effects of low levels of oxygen, glucose, and $\mathrm{pH}$ on rates of energy metabolism of bovine nucleus pulposus cells. Spine 2005, 30, 487-496. [CrossRef] [PubMed]

54. Ishihara, H.; Urban, J.P. Effects of low oxygen concentrations and metabolic inhibitors on proteoglycan and protein synthesis rates in the intervertebral disc. J Orthop. Res. 1999, 17, 829-835. [CrossRef]

55. Bibby, S.R.; Urban, J.P. Effect of nutrient deprivation on the viability of intervertebral disc cells. Eur. Spine J. 2004, 13, 695-701. [CrossRef]

56. Ohshima, H.; Urban, J.P. The effect of lactate and $\mathrm{pH}$ on proteoglycan and protein synthesis rates in the intervertebral disc. Spine 1992, 17, 1079-1082. [CrossRef]

57. Razaq, S.; Wilkins, R.J.; Urban, J.P. The effect of extracellular $\mathrm{pH}$ on matrix turnover by cells of the bovine nucleus pulposus. Eur. Spine J. 2003, 12, 341-349. [CrossRef]

58. Bernick, S.; Cailliet, R. Vertebral end-plate changes with aging of human vertebrae. Spine 1982, 7, 97-102. [CrossRef]

59. Grant, M.P.; Epure, L.M.; Bokhari, R.; Roughley, P.; Antoniou, J.; Mwale, F. Human cartilaginous endplate degeneration is induced by calcium and the extracellular calcium-sensing receptor in the intervertebral disc. Eur. Cell Mater. 2016, 32, 137-151. [CrossRef]

60. Boos, N.; Weissbach, S.; Rohrbach, H.; Weiler, C.; Spratt, K.F.; Nerlich, A.G. Classification of age-related changes in lumbar intervertebral discs: 2002 Volvo Award in basic science. Spine 2002, 27, 2631-2644. [CrossRef]

61. Garfin, S.R.; Eismont, F.J.; Bell, G.R.; Bono, C.M.; Fischgrund, J.S. The Intervertebral Disc: Normal, Aging, and Pathologic. In Rothman-Simeone and Herkowitz's the Spine, 7th ed.; Olsen, S.A., Kang, J.D., Vo, N.V., Sowa, G.A., Eds.; Elsevier: Amsterdam, The Netherlands, 2018; Volume 2, pp. 79-89.

62. Eyre, D.R.; Muir, H. Types I and II collagens in intervertebral disc. Interchanging radial distributions in annulus fibrosus. Biochem. J. 1976, 157, 267-270. [CrossRef] [PubMed]

63. Duance, V.C.; Crean, J.K.; Sims, T.J.; Avery, N.; Smith, S.; Menage, J.; Eisenstein, S.M.; Roberts, S. Changes in collagen cross-linking in degenerative disc disease and scoliosis. Spine 1998, 23, 2545-2551. [CrossRef] 
64. Madhu, V.; Boneski, P.K.; Silagi, E.; Qiu, Y.; Kurland, I.; Guntur, A.R.; Shapiro, I.M.; Risbud, M.V. Hypoxic Regulation of Mitochondrial Metabolism and Mitophagy in Nucleus Pulposus Cells Is Dependent on HIF-1 $\alpha$-BNIP3 Axis. J. Bone Miner. Res. 2020, 35, 1504-1524. [CrossRef]

65. Huang, Y.; Wang, Y.; Wu, C.; Tian, W. Elevated expression of hypoxia-inducible factor-2 $\alpha$ regulated catabolic factors during intervertebral disc degeneration. Life Sci. 2019, 232, 116565. [CrossRef]

66. Buckley, D.L.; Van Molle, I.; Gareiss, P.C.; Tae, H.S.; Michel, J.; Noblin, D.J.; Jorgensen, W.L.; Ciulli, A.; Crews, C.M. Targeting the von Hippel-Lindau E3 ubiquitin ligase using small molecules to disrupt the VHL/HIF-1alpha interaction. J. Am. Chem. Soc. 2012, 134, 4465-4468. [CrossRef] [PubMed]

67. Liu, Y.; Lei, Y.; Guo, S.; Zuo, Z. Ensemble-based virtual screening in discovering potent inhibitors targeting Von Hippel-Lindau (VHL) E3 ubiquitin ligase. Life Sci. 2020, 262, 118495. [CrossRef]

68. Mahon, P.C.; Hirota, K.; Semenza, G.L. FIH-1: A novel protein that interacts with HIF-1alpha and VHL to mediate repression of HIF-1 transcriptional activity. Genes Dev. 2001, 15, 2675-2686. [CrossRef]

69. Chen, T.; Ren, Z.; Ye, L.C.; Zhou, P.H.; Xu, J.M.; Shi, Q.; Yao, L.Q.; Zhong, Y.S. Factor inhibiting HIF1alpha (FIH-1) functions as a tumor suppressor in human colorectal cancer by repressing HIF1alpha pathway. Cancer Biol. Ther. 2015, 16, 244-252. [CrossRef] [PubMed]

70. Feng, X.; Yu, X.; Pang, M.; Tong, J. Molecular characterization and expression regulation of the factor-inhibiting HIF-1 (FIH-1) gene under hypoxic stress in bighead carp (Aristichthys nobilis). Fish. Physiol. Biochem. 2019, 45, 657-665. [CrossRef] [PubMed]

71. Park, J.B.; Chang, H.; Kim, K.W. Expression of Fas ligand and apoptosis of disc cells in herniated lumbar disc tissue. Spine 2001, 26, 618-621. [CrossRef]

72. Zhu, G.B.; Jiang, X.R.; Xia, C.L.; Sun, Y.J.; Zeng, Q.S.; Wu, X.M.; Li, X.C. Association of FAS and FAS ligand polymorphisms with the susceptibility and severity of lumbar disc degeneration in Chinese Han population. Biomarkers 2011, 16, 485-490. [CrossRef]

73. Richardson, S.M.; Kalamegam, G.; Pushparaj, P.N.; Matta, C.; Memic, A.; Khademhosseini, A.; Mobasheri, R.; Poletti, F.L.; Hoyland, J.A.; Mobasheri, A. Mesenchymal stem cells in regenerative medicine: Focus on articular cartilage and intervertebral disc regeneration. Methods 2016, 99, 69-80. [CrossRef]

74. Vasiliadis, E.S.; Pneumaticos, S.G.; Evangelopoulos, D.S.; Papavassiliou, A.G. Biologic treatment of mild and moderate intervertebral disc degeneration. Mol. Med. 2014, 20, 400-409. [CrossRef]

75. Wang, S.Z.; Chang, Q.; Lu, J.; Wang, C. Growth factors and platelet-rich plasma: Promising biological strategies for early intervertebral disc degeneration. Int. Orthop. 2015, 39, 927-934. [CrossRef] [PubMed]

76. Chen, S.; Fang, X.Q.; Wang, Q.; Wang, S.W.; Hu, Z.J.; Zhou, Z.J.; Xu, W.B.; Wang, J.Y.; Qin, A.; Fan, S.W. PHD/HIF-1 upregulates CA12 to protect against degenerative disc disease: A human sample, in vitro and ex vivo study. Lab. Investig. 2016, 96, 561-569. [CrossRef]

77. Feng, G.; Li, L.; Hong, Y.; Liu, H.; Song, Y.; Pei, F.; Ma, P.X.; Gong, Q.; Gupte, M.J. Hypoxia promotes nucleus pulposus phenotype in 3D scaffolds in vitro and in vivo: Laboratory investigation. J. Neurosurg. Spine 2014, 21, 303-309. [CrossRef] [PubMed]

78. Feng, G.; Li, L.; Liu, H.; Song, Y.; Huang, F.; Tu, C.; Shen, B.; Gong, Q.; Li, T.; Liu, L.; et al. Hypoxia differentially regulates human nucleus pulposus and annulus fibrosus cell extracellular matrix production in 3D scaffolds. Osteoarthr. Cartil. 2013, 21, 582-588. [CrossRef] [PubMed]

79. Wang, X.; Lv, G.; Li, J.; Wang, B.; Zhang, Q.; Lu, C. LncRNA-RP11-296A18.3/miR-138/HIF1A Pathway Regulates the Proliferation ECM Synthesis of Human Nucleus Pulposus Cells (HNPCs). J. Cell Biochem. 2017, 118, 4862-4871. [CrossRef] [PubMed]

80. Hiyama, A.; Skubutyte, R.; Markova, D.; Anderson, D.G.; Yadla, S.; Sakai, D.; Mochida, J.; Albert, T.J.; Shapiro, I.M.; Risbud, M.V. Hypoxia activates the notch signaling pathway in cells of the intervertebral disc: Implications in degenerative disc disease. Arthritis Rheum. 2011, 63, 1355-1364. [CrossRef]

81. Liu, Z.; Li, C.; Meng, X.; Bai, Y.; Qi, J.; Wang, J.; Zhou, Q.; Zhang, W.; Zhang, X. Hypoxia-inducible factor-lalpha mediates aggrecan and collagen Pi expression via NOTCH1 signaling in nucleus pulposus cells during intervertebral disc degeneration. Biochem. Biophys. Res. Commun. 2017, 488, 554-561. [CrossRef]

82. Tannenbaum, A.; Silverstone, H. Failure to inhibit the formation of mammary carcinoma in mice by intermittent fasting. Cancer Res. 1950, 10, 577-579. [PubMed]

83. Benita, Y.; Kikuchi, H.; Smith, A.D.; Zhang, M.Q.; Chung, D.C.; Xavier, R.J. An integrative genomics approach identifies Hypoxia Inducible Factor-1 (HIF-1)-target genes that form the core response to hypoxia. Nucleic Acids Res. 2009, 37, 4587-4602. [CrossRef] [PubMed]

84. Papandreou, I.; Cairns, R.A.; Fontana, L.; Lim, A.L.; Denko, N.C. HIF-1 mediates adaptation to hypoxia by actively downregulating mitochondrial oxygen consumption. Cell Metab. 2006, 3, 187-197. [CrossRef] [PubMed]

85. Golub, E.E. Biomineralization and matrix vesicles in biology and pathology. Semin. Immunopathol. 2011, 33, 409-417. [CrossRef]

86. Kirsch, T. Determinants of pathological mineralization. Curr. Opin. Rheumatol. 2006, 18, 174-180. [CrossRef]

87. Shao, J.; Yu, M.; Jiang, L.; Wei, F.; Wu, F.; Liu, Z.; Liu, X. Differences in calcification and osteogenic potential of herniated discs according to the severity of degeneration based on Pfirrmann grade: A cross-sectional study. BMC Musculoskelet. Disord. 2016, 17, 191. [CrossRef]

88. Guiot, B.H.; Fessler, R.G. Molecular biology of degenerative disc disease. Neurosurgery 2000, 47, 1034-1040. [CrossRef]

89. Pendleton, A.; Johnson, M.D.; Hughes, A.; Gurley, K.A.; Ho, A.M.; Doherty, M.; Dixey, J.; Gillet, P.; Loeuille, D.; McGrath, R.; et al. Mutations in ANKH cause chondrocalcinosis. Am. J. Hum. Genet. 2002, 71, 933-940. [CrossRef] 
90. Williams, C.J.; Pendleton, A.; Bonavita, G.; Reginato, A.J.; Hughes, A.E.; Peariso, S.; Doherty, M.; McCarty, D.J.; Ryan, L.M. Mutations in the amino terminus of ANKH in two US families with calcium pyrophosphate dihydrate crystal deposition disease. Arthritis Rheum. 2003, 48, 2627-2631. [CrossRef]

91. Liu, M.H.; Sun, C.; Yao, Y.; Fan, X.; Liu, H.; Cui, Y.H.; Bian, X.W.; Huang, B.; Zhou, Y. Matrix stiffness promotes cartilage endplate chondrocyte calcification in disc degeneration via miR-20a targeting ANKH expression. Sci. Rep. 2016, 6, 25401. [CrossRef] [PubMed]

92. Takahashi, S. Vascular endothelial growth factor (VEGF), VEGF receptors and their inhibitors for antiangiogenic tumor therapy. Biol. Pharm. Bull. 2011, 34, 1785-1788. [CrossRef] [PubMed]

93. Han, I.B.; Ropper, A.E.; Teng, Y.D.; Shin, D.A.; Jeon, Y.J.; Park, H.M.; Shin, D.E.; Park, Y.S.; Kim, K.N.; Kim, N.K. Association between VEGF and eNOS gene polymorphisms and lumbar disc degeneration in a young Korean population. Genet. Mol. Res. 2013, 12, 2294-2305. [CrossRef] [PubMed]

94. Haro, H.; Kato, T.; Komori, H.; Osada, M.; Shinomiya, K. Vascular endothelial growth factor (VEGF)-induced angiogenesis in herniated disc resorption. J. Orthop. Res. 2002, 20, 409-415. [CrossRef]

95. Doita, M.; Kanatani, T.; Ozaki, T.; Matsui, N.; Kurosaka, M.; Yoshiya, S. Influence of macrophage infiltration of herniated disc tissue on the production of matrix metalloproteinases leading to disc resorption. Spine 2001, 26, 1522-1527. [CrossRef] [PubMed]

96. Kwon, W.K.; Moon, H.J.; Kwon, T.H.; Park, Y.K.; Kim, J.H. The Role of Hypoxia in Angiogenesis and Extracellular Matrix Regulation of Intervertebral Disc Cells During Inflammatory Reactions. Neurosurgery 2017, 81, 867-875. [CrossRef]

97. Wu, W.J.; Zhang, X.K.; Zheng, X.F.; Yang, Y.H.; Jiang, S.D.; Jiang, L.S. SHH-dependent knockout of HIF-1 alpha accelerates the degenerative process in mouse intervertebral disc. Int. J. Immunopathol. Pharmacol. 2013, 26, 601-609. [CrossRef]

98. Mazure, N.M.; Pouysségur, J. Hypoxia-induced autophagy: Cell death or cell survival? Curr. Opin. Cell Biol. 2010, 22, 177-180. [CrossRef]

99. Scherz-Shouval, R.; Elazar, Z. Regulation of autophagy by ROS: Physiology and pathology. Trends Biochem. Sci. 2011, 36, 30-38. [CrossRef]

100. Tu, J.; Li, W.; Li, S.; Liu, W.; Zhang, Y.; Wu, X.; Luo, R.; Hua, W.; Wang, K.; Song, Y.; et al. Sestrin-Mediated Inhibition of StressInduced Intervertebral Disc Degradation Through the Enhancement of Autophagy. Cell Physiol. Biochem. 2018, 45, 1940-1954. [CrossRef]

101. Chen, J.W.; Ni, B.B.; Zheng, X.F.; Li, B.; Jiang, S.D.; Jiang, L.S. Hypoxia facilitates the survival of nucleus pulposus cells in serum deprivation by down-regulating excessive autophagy through restricting ROS generation. Int. J. Biochem. Cell Biol. 2015, 59, 1-10. [CrossRef]

102. Ding, F.; Shao, Z.W.; Xiong, L.M. Cell death in intervertebral disc degeneration. Apoptosis 2013, 18, 777-785. [CrossRef] [PubMed]

103. Gruber, H.E.; Hanley, E.N., Jr. Analysis of aging and degeneration of the human intervertebral disc. Comparison of surgical specimens with normal controls. Spine 1998, 23, 751-757. [CrossRef] [PubMed]

104. Zhou, X.; Li, J.; Teng, J.; Liu, Y.; Zhang, D.; Liu, L.; Zhang, W. microRNA-155-3p attenuates intervertebral disc degeneration via inhibition of KDM3A and HIF1 $\alpha$. Inflamm. Res. 2021, 70, 297-308. [CrossRef] [PubMed]

105. Wang, W.; Deng, G.; Qiu, Y.; Huang, X.; Xi, Y.; Yu, J.; Yang, X.; Ye, X. Transplantation of allogenic nucleus pulposus cells attenuates intervertebral disc degeneration by inhibiting apoptosis and increasing migration. Int. J. Mol. Med. 2018, 41, 2553-2564. [CrossRef] [PubMed]

106. Huang, Z.; Zhang, L.; Feng, X.; Chen, T.; Bi, S. A new in vivo method to retard progression of intervertebral disc degeneration through stimulation of endogenous stem cells with simvastatin. Med. Hypotheses 2017, 101, 65-66. [CrossRef] [PubMed]

107. Guo, W.; Zhang, B.; Mu, K.; Feng, S.Q.; Dong, Z.Y.; Ning, G.Z.; Li, H.R.; Liu, S.; Zhao, L.; Li, Y.; et al. Circular RNA GRB10 as a competitive endogenous RNA regulating nucleus pulposus cells death in degenerative intervertebral disk. Cell Death Dis. 2018, 9 , 319. [CrossRef] [PubMed] 